\title{
Changes in oestrous cyclicity following olfactory bulbectomy in post-pubertal pigs
}

\author{
W. D. Booth and B. A. Baldwin* \\ A.R.C. Institute of Animal Physiology, Animal Research Station, 307 Huntingdon Road, Cambridge \\ CB3 OJQ, U.K. and *A.R.C. Institute of Animal Physiology, Babraham, Cambridge \\ CB2 4AT, U.K.
}

\begin{abstract}
Summary. Bilateral olfactory bulbectomy was carried out on 16 post-pubertal gilts during the winter and spring of 2 consecutive years. Eight bulbectomized gilts in Exp. 1 had 2-7 regular periods of oestrus before becoming anoestrous for $>100$ days in the summer and autumn. During November, 3 of these gilts were placed with a boar and became oestrous within 9 days, were mated and established normal pregnancies; the remaining pigs also resumed normal oestrous cycles when transferred to other pens. The following year anoestrus again occurred during the summer in gilts and in sows after weaning. In Exp. 2, 8 bulbectomized gilts remained in the same pens throughout the experiment, 4 were housed with a vasectomized boar and 4 away from boars. As in Exp. 1, the same periods of anoestrus occurred throughout the year, whereas 4 unoperated pigs housed nearby had continuous oestrous cycles.

Ovulation without oestrus occurred in some bulbectomized pigs even after gonadotrophin treatment. Prolonged anoestrus in Exp. 1 was associated with nonovulatory levels of plasma oestrogen and low plasma progesterone and $\mathrm{LH}$ values. Behavioural, morphological and endocrine data indicate that the effects of bulbectomy on oestrous cycles in post-pubertal gilts are mediated at the hypothalamus. The seasonality of the effects seems likely to be due to bulbectomy unmasking a photoperiodic influence.
\end{abstract}

\section{Introduction}

Olfactory impairment brought about by removal of the olfactory bulbs, has been used to demonstrate the importance of olfaction in reproduction with particular reference to sexual and maternal behaviours and the regulation of gonadal function (Murphy, 1976). In small mammals such as the mouse (Lamond, 1958; Vandenbergh, 1973) and hamster (Carter, 1973), olfactory bulbectomy leads to irregular oestrous cycles. Of the large mammals, the pig has a very well developed sense of smell, and experiments have been carried out on the role of olfaction in reproduction in this species (Hafez \& Signoret, 1969; Booth, 1980). Signoret \& Mauléon (1962) found that olfactory bulbectomy in post-pubertal gilts resulted in prolonged anoestrus when the removal of bulb tissue was complete, but there was no effect on oestrous cycles in pigs with partial lesions of the olfactory bulbs or in sham-operated animals. However, bilateral olfactory bulbectomy in prepubertal gilts had no adverse effect on their ability to mate and produce normal litters when they were mature (Meese \& Baldwin, 1975) although it was possible that puberty may have been delayed (Kirkwood, Forbes \& Hughes, 1981). Olfactory bulbectomy in prepubertal boars had no significant effect on their sexual maturation (Booth \& Baldwin, 1980). 
In view of the apparent differences in the degree of disruption of ovarian activity depending on whether gilts are bulbectomized before or after puberty, we (1) re-examined the work of Signoret \& Mauléon (1962) and obtained more detailed endocrine data, and (2) determined whether any induced anoestrus was permanent.

\section{Materials and Methods}

The findings of an initial study (Exp. 1) prompted the design of a second investigation (Exp. 2). For Exp. 1, 6 prepubertal Large White and 2 prepubertal cross-bred gilts aged 18 weeks were used. The pigs were housed in partly covered pens adjacent to a mature boar. Twelve similar pigs were used for Exp. 2.

\section{Detection of oestrus}

An established testing boar was introduced daily to the gilts and first oestrus was detected by the lordosis response to back pressure. The mean age at first oestrus for the pigs in Exp. 1 was 217 days; this information was not available in Exp. 2.

The same standard procedure for oestrus detection was carried out after olfactory bulbectomy, except that in Exp. 2 a testing boar was not introduced to the animals that were housed permanently with a vasectomized boar.

\section{Removal of olfactory bulbs}

Olfactory bulbectomy was carried out during the late luteal phase of the cycle following the 2 nd or 3rd oestrus between January and June. The olfactory bulbs were removed by suction (Signoret \& Mauléon, 1962; Meese \& Baldwin, 1975), extreme care being taken not to damage the preoptic region of the brain. Post-operative recovery was rapid and no abnormal neurological signs were seen. All 8 pigs in Exp. 1, and 8 of the 12 pigs in Exp. 2 were bulbectomized; the remaining 4 pigs in Exp. 2 served as controls.

\section{Post-operative housing}

Since the pre-operative cycles in the pigs in Exp. 1 were more or less synchronized in pairs, these pigs were bulbectomized in pairs and subsequently housed one pair to a pen in a part of the piggery away from visual contact with boars. By early November, all pigs in Exp. 1 had been anoestrous for over 100 days. Three of these pigs (Nos 6170,6711 and 6730) were then transferred to another pen and kept with a fertile boar. At the same time the remaining 4 pigs (one had died for reasons apparently unconnected with the experiment), were transferred in pairs to other pens.

In Exp. 2, 4 of the bulbectomized pigs were housed as a group with one of 2 vasectomized boars in a partly covered pen, and the boars were changed every month. The remaining 4 bulbectomized pigs were housed as a group in a covered pen which allowed natural daylight to enter, and in a part of the piggery where there were no boars. The 4 unoperated gilts were housed in a pen adjacent to the bulbectomized pigs without a boar. All pigs in Exp. 2 remained in the same pens throughout the investigation.

\section{Hormone assays}

Blood samples $(20 \mathrm{ml})$ were collected into heparinized syringes every $3-4$ days from the anterior vena cava of all pigs in Exp. 1, starting after the oestrus immediately preceding bulbectomy. Blood samples were not collected during the 14 days after surgery but were then collected every 3-4 days 
during the 2 nd and 3rd post-operative cycles, and at longer intervals as soon as the pigs became anoestrous. The blood was centrifuged and the plasma stored at $-20^{\circ} \mathrm{C}$ until required for hormone analysis. Total unconjugated oestrogen and progesterone were determined by radioimmunoassays based on those described by Henricks, Guthrie \& Handlin (1972) and Guthrie, Henricks \& Handlin (1972). Details concerning the supply of antisera against oestrogen and progesterone, and crossreactions of various steroids to the antisera, and the supply of tracer steroids have been described by Newcomb, Booth \& Rowson (1977). The progesterone radioimmunoassay was modified so that the steroid was measured directly in the plasma without solvent extraction as described by Newcomb et al. (1977). The within- and between-assay coefficients of variation for progesterone were $<18 \%$, and the within- and between-assay coefficients of variation for total unconjugated oestrogen were $<11 \%$. The minimum amounts of progesterone and oestrogen that were distinguishable from the blank were about $20 \mathrm{pg}$ and $5 \mathrm{pg}$ respectively. $\mathrm{LH}$ was measured by radioimmunoassay as described by Niswender, Reichert \& Zimmerman (1970), using porcine LH (LH-GPZ-1); the potency and purification of $\mathrm{LH}$ and the radioiodination technique have been described previously (Ziecik, Goralska, Krzymowski \& Pogorzelski, 1978). LH was measured in all plasma samples in one assay, details of the specificity, reproducibility and sensitivity are published elsewhere (Garverick, Polge \& Flint, 1982).

\section{Morphological characteristics}

None of the pigs was killed before 18-30 months after bulbectomy so that the incidence of anoestrus could be monitored over a period of at least 1 year. After slaughter the reproductive tracts and heads were examined, and the status of the ovary with reference to the gross appearance of follicles, corpora lutea and corpora albicantia was noted, and the length of each uterine horn was measured. The heads were dissected to expose the ethmoturbinate bones with overlying olfactory epithelium, the ethmoid fossa and cribriform plate, and the forebrain. Samples of olfactory epithelium were removed from the ethmoturbinate bones and processed for histology and histometric analysis as described by Booth \& Baldwin (1980).

\section{Results}

\section{Experiment 1}

After bulbectomy the pigs had a variable number of regular manifestations of oestrus before entering a long period of continuous anoestrus during the summer of 1979 (Table 1). At the

Table 1. Alternating periods of behavioural oestrus and anoestrus after olfactory bulbectomy in postpubertal gilts (Exp.1)

\begin{tabular}{ccccccc}
\hline & $\begin{array}{c}\text { Oestrous } \\
\text { periods (I) } \\
\text { Pig No. } \\
\text { (post-bulbectomy) }\end{array}$ & $\begin{array}{c}\text { Anoestrous } \\
\text { period (I) } \\
\text { (days) }\end{array}$ & $\begin{array}{c}\text { Change of habitat } \\
\text { (November 1979) }\end{array}$ & $\begin{array}{c}\text { Oestrous } \\
\text { periods (II) }\end{array}$ & $\begin{array}{c}\text { Anoestrous } \\
\text { period (II) } \\
\text { (days) }\end{array}$ & $\begin{array}{c}\text { Oestrous } \\
\text { periods (III) }\end{array}$ \\
\hline 6710 & 5 & 132 & Pen with & 1 (Mated) + 3* & 61 & - \\
6711 & 7 & 118 & fertile boar & 1 (Mated) + 1* & 98 & - \\
6370 & 2 & 223 & & 1 (Mated) $+1^{*}$ & 53 & - \\
6712 & 3 & 165 & Pen without & 11 & 121 & 4 \\
6728 & 3 & 162 & boar & 5 & 475 & - \\
B16L & 2 & 140 & & 10 & 132 & 5 \\
B56J & 2 & 206 & 3 & 248 & - \\
\hline
\end{tabular}

* Normal pregnancy + oestrus after weaning.

Pigs were slaughtered during summer 1980 (2nd anoestrus), or during the period of cyclicity that started in December 1980 (3rd oestrus). 
beginning of November 1979 , the 3 pigs transferred to a pen containing a fertile boar returned to oestrus within 9 days and all were mated. A normal pregnancy and parturition ensued. No postpartum heat occurred in any of the sows, and there was a long delay before the pigs returned to oestrus after weaning the piglets at 8 weeks. The first oestrus after weaning in Sow 6711 occurred 53 days after weaning, but oestrus did not then recur. Sow 6730 had not been in oestrus by 87 days after weaning and was given a single injection of oestradiol benzoate $(5 \mathrm{mg})$; oestrus occurred 5 days later, but not thereafter. Sow 6710 did not exhibit oestrus until 94 days after farrowing; 2 further oestrous periods then occurred before anoestrus. Subsequently, a single injection of PMSG (625 i.u., Folligon: Intervet Laboratories Ltd, Cambridge, U.K.) combined with hCG (250 i.u., Chorulon: Intervet) given to all 3 sows during the anoestrus did not induce a behavioural oestrus although the vulvas became red and swollen. A repeat injection of PMSG + hCG 2 weeks later, followed 5 days later by an injection of hCG (500 i.u.) also failed to induce a behavioural oestrus (Table 2). The pigs were slaughtered 4 days after the second injection of hCG; the appearance of the ovaries in Sows 6711 and 6730 showed that the pigs had ovulated whereas the ovaries in Sow 6710 had not responded to gonadotrophin treatment (Table 2).

When the remaining pigs were transferred to other pens during November 1979 while they were anoestrous, they began to show regular behavioural oestrus within 1 month of being rehoused. However, during the spring and summer of 1980 , these pigs entered a prolonged period of anoestrus for the second time (Table 1). During this second anoestrous period one of the pigs (No. B56J) died due to an infection of Clostridium oedematiens. Pig 6728 was given PMSG and hCG, and at slaughter was seen to have ovulated although this had not been preceded by a behavioural oestrus (Table 2). The remaining 2 pigs (Nos 6712 and $\mathrm{B} 16 \mathrm{~L}$ ) returned to regular cycles during late November and early December 1980 (Table 1). When these 2 pigs were slaughtered in February 1981 while they were still cyclic, the reproductive tract appeared normal and young corpora lutea were present (Table 2).

Hormone profiles showed normal cyclic fluctuations during the period when oestrous cycles were regular in the pre-operative and early post-bulbectomy period. During the ensuing prolonged anoestrous period after bulbectomy, oestrogen remained at non-ovulatory levels $(10-30 \mathrm{pg} / \mathrm{ml})$ while progesterone and $\mathrm{LH}$ were low $(<0.5 \mathrm{ng} / \mathrm{ml}$ and $<1 \mathrm{ng} / \mathrm{ml}$ respectively).

\section{Experiment 2}

The incidence of behavioural oestrus and anoestrus after olfactory bulbectomy in the pigs in Exp. 2 (Text-fig. 1) followed a pattern similar to that for pigs in Exp. 1. Anoestrus was particularly

Table 2. Reproductive status of post-pubertally bulbectomized pigs (Exp. 1) immediately before and at slaughter

\begin{tabular}{cllccc}
\hline Pig No. & $\begin{array}{c}\text { Oestrous } \\
\text { cycles* }\end{array}$ & Treatment & $\begin{array}{c}\text { Oestrous response } \\
\text { to boar }\end{array}$ & $\begin{array}{c}\text { Date of } \\
\text { slaughter }\end{array}$ & $\begin{array}{c}\text { No. of CL } \\
\text { at slaughter } \dagger\end{array}$ \\
\hline 6710 & Anoestrus (II) & PMSG + hCG & None & Oct. 1980 & None \\
6711 & Anoestrus (II) & PMSG + hCG & None & Oct. 1980 & 28 \\
6730 & Anoestrus (II) & PMSG + hCG & None & Oct. 1980 & 20 \\
6728 & Anoestrus (II) & PMSG + hCG & None & June 1981 & $32 \ddagger$ \\
6712 & Oestrus (III) & None & + & Feb. 1981 & 25 \\
B16L & Oestrus (III) & None & + & Feb. 1981 & 18 \\
B56J & Anoestrus (II) & None & None & Nov. 1980 & None \\
\hline
\end{tabular}

* Assessed on ability to show behavioural oestrus in the presence of a boar. No. in parentheses indicates episodic sequence in duration of experiment (see Table 1).

† The development of follicles and uterine horns was similar to that shown in Table 3 for pigs of comparable reproductive status.

$\ddagger$ Recent corpora albicantia indicating previous ovulation without oestrus. 


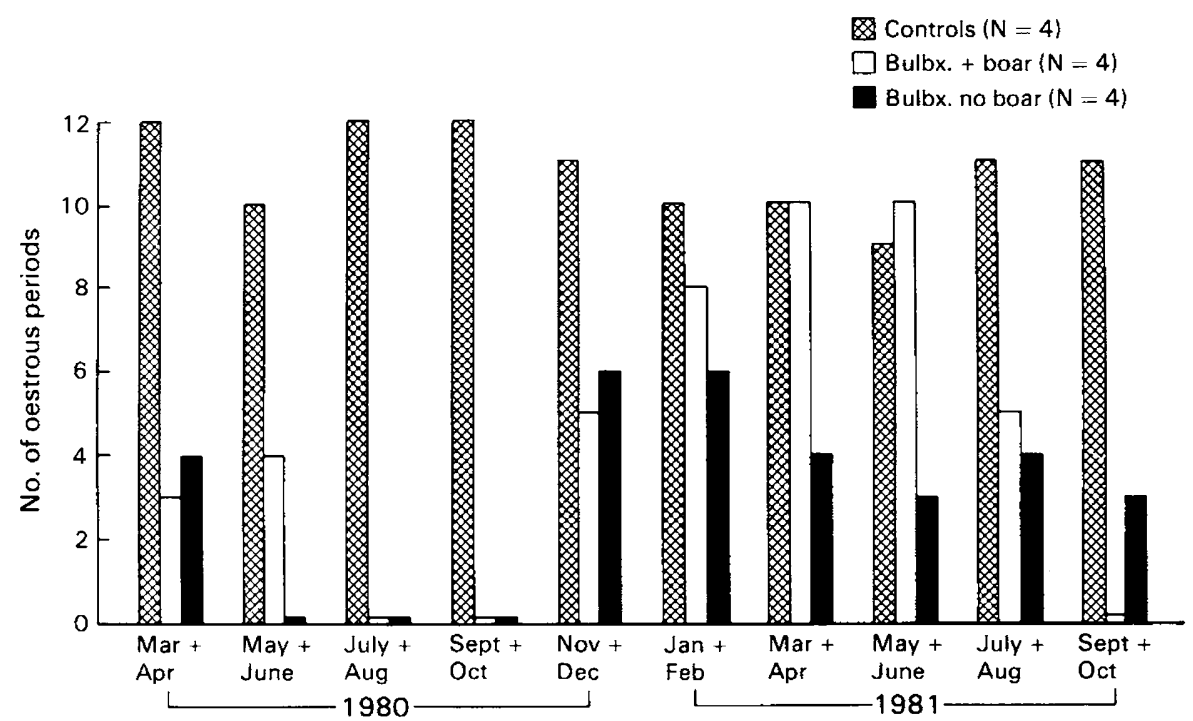

Text-fig. 1. Incidence of behavioural oestrus over a period of 20 months following olfactory bulbectomy in 8 post-pubertal gilts (Exp. 2).

marked during the summer and early autumn after bulbectomy. As in Exp. 1, regular oestrous cycles were resumed during November and December. During the 2nd year (1981) after bulbectomy, the incidence of anoestrus was less marked, particularly in the pigs kept with a vasectomized boar, but by October all pigs in this group were anoestrous, whereas 2 of the 4 pigs housed away from boars were cyclic. All pigs were slaughtered during early November 1981. Generally, the appearance of the reproductive tracts confirmed the reproductive condition of the pigs as indicated by the incidence of behavioural oestrus (Table 3). (An exception was Pig C39A which was behaviourally anoestrous, but showed young corpora lutea and large corpora albicantia and well developed uterine horns.) Although the persistently anoestrous Pig $\mathrm{C} 10$ had relatively long

Table 3. Reproductive status of post-pubertally bulbectomized pigs (Exp. 2) immediately before and at slaughter

\begin{tabular}{cccccc}
\hline & & & \multicolumn{2}{c}{ Condition of reproductive tract at slaughter } \\
\cline { 4 - 6 } Pig No. & Habitat & $\begin{array}{c}\text { Oestrous } \\
\text { cycles* }\end{array}$ & Follicles (mm) & No. of CL & $\begin{array}{c}\text { Mean uterine } \\
\text { horn length (cm) }\end{array}$ \\
\hline C30 & With & Anoestrus (II) & $2-5$ & None & 88 \\
C56 & vasectomized & Anoestrus (II) & $2-5$ & None & 59 \\
C38A & boar & Anoestrus (II) & $2-5$ & None & 84 \\
C20B & & Anoestrus (II) & $2-5$ & None & 68 \\
C10 & Testing boar & Anoestrus (I) $\dagger$ & $2-5$ & None & $117 \dagger$ \\
C19 & once daily & Oestrus (III) & $2-5$ & 18 & 200 \\
C57 & & Oestrus (III) & 1 & 20 & 141 \\
C39A & & Anoestrus (II) & $<2$ & $22 \ddagger$ & 102 \\
\hline
\end{tabular}

* Assessed on ability to show behavioural oestrus in the presence of a boar. No. in parentheses indicates episodic sequence in duration of experiment (see Table I).

$\dagger$ Anoestrous since bulbectomy, thin-walled uteri, small broad ligament.

$\ddagger$ Large young corpora lutea indicating recent ovulation. 
uterine horns, they were very thin walled, the ovaries were prepubertal in appearance with numerous small follicles and complete absence of corpora lutea or distinct corpora albicantia.

A characteristic of all the bulbectomized pigs in Exps 1 and 2 was that they required considerable stimulation by the boar before they displayed behavioural oestrus, and it was unusual for the sow to stand to the boar for more than 1 day. In contrast the 4 unoperated control sows responded readily to the boar and the regular oestrous periods usually lasted at least 2 days (Textfig. 1).

\section{Olfactory region at slaughter}

In all the bulbectomized pigs the gross anatomical appearance of the ethmoid fossa and forebrain region showed that no olfactory bulb tissue was present, and that the preoptic region was intact. The forebrain had partly occupied the ethmoid fossa and was separated from the cribriform plate by connective tissue, which in some pigs had ossified to form a thin plate of bone. The perforations in the cribriform plate which allow the axons of the receptor cells in the olfactory epithelium to make contact with the olfactory bulbs, were occluded with bone in the bulbectomized pigs.

The height (mean \pm s.e.m.) of the olfactory epithelium overlying the ethmoturbinate bones in the bulbectomized pigs was $82.4 \pm 2.70 \mu \mathrm{m}$ (left side), and $85.4 \pm 3.17 \mu \mathrm{m}$ (right side) in Exp. 1 , and $70.7 \pm 5.49 \mu \mathrm{m}$ (left side), and $85 \pm 9.53 \mu \mathrm{m}$ (right side) in Exp. 2. The height of the olfactory epithelium in the present study was comparable to that found previously in bulbectomized pigs (Booth \& Baldwin, 1980), and was in keeping with the maximum degree of regeneration seen after bulbectomy (Booth, Baldwin, Poynder, Bannister \& Gower, 1981).

\section{Discussion}

The results confirmed the findings of Signoret \& Mauléon (1962) that total olfactory bulbectomy in post-pubertal female pigs leads to prolonged anoestrus lasting at least 100 days. However, the present study has also provided more information on the effects of olfactory bulbectomy in relation to other factors which are known to be involved in the regulation of ovarian function.

The return to oestrus which soon followed the change of habitat in Exp. 1, particularly in those pigs cohabiting with a boar, could have been due to transporting the pigs to a new environment, with an additional stimulus if a boar was present, or may have been caused by a seasonal effect. There was also the possibility that all these factors were involved. Experiment 2 was designed to examine at least two of the possible influences on oestrous cyclicity. The fact that anoestrus again occurred during the summer months in all pigs regardless of whether they were cohabiting with a vasectomized boar, and that regular oestrous cycles were resumed in late autumn when the pigs remained in their home pens, strongly indicated that a seasonal component was involved in initiating the return of regular oestrous cycles.

Other studies have shown that cyclic ovarian activity in the pig in the northern hemisphere is more readily initiated during the late autumn to spring. For example, exogenous oestrogen is most effective in inducing puberty in late autumn and winter (Foxcroft, 1979), and Hurtgen, Leman \& Crabo (1980) found the interval between weaning and first oestrus in the sow was shorter at this time of the year. Conversely, in the present study the 3 sows with piglets that were weaned in early summer, had a long delay before their first oestrus after weaning, and then failed to maintain regular oestrous cycles. This finding was coincident with the summer anoestrus which occurred in the non-pregnant bulbectomized gilts, and to a lesser extent in a normal population of pigs studied by Hurtgen et al. (1980). Related to these findings is the annual pattern of ovarian activity in the European wild boar, in which a post-weaning oestrus does not occur until late autumn if lactation extends to late June from a farrowing in the spring, or if farrowing occurs during August or $_{\text {oct }}$ 
September (Mauget, 1982). The overall effect of these two breeding states is that most pigs (including unmated females) in the population are anoestrous from June to December; regular oestrous cycles are resumed between December and May.

In the wild boar it seems that nutrition can influence ovarian activity in so far as oestrous cycles are resumed earlier in the autumn when food is plentiful. However, Mauget (1982) concludes that a photoperiodic factor is the most likely environmental stimulus involved in the maintenance of the anoestrous state following lactation, and subsequent resumption of oestrous cycles in the winter. Although the domestic pig is generally not considered to be a seasonally breeding animal, evidence obtained from the present study on bulbectomized pigs for which nutrition was constant, and that of Hurtgen et al. (1980) in which anoestrus did not appear to be related to temperature changes, suggests that a photoperiodic factor might influence the maintenance of cyclic ovarian activity in the domestic pig.

Since anoestrus in the wild pig is associated with high levels of plasma prolactin (Mauget, 1982), it has yet to be determined whether anoestrus following bulbectomy is also associated with high levels of this hormone. Plasma LH and progesterone values were low during prolonged anoestrus in Exp. 1 and this agrees with the histological appearance of the pituitaries in the study of Signoret \& Mauléon (1962) which indicated a reduced secretion of gonadotrophins after bulbectomy. The anoestrus after bulbectomy therefore seems to be due to a deficiency in gonadotrophin secretion. The frequent occurrence of ovulation without oestrus after bulbectomy indicates that the lack of olfactory stimulus affected the centres in the brain concerned with the lordosis response (behavioural oestrus; Lisk, 1978). The olfactory bulb has neural connections with the preoptic region and hypothalamus through the medial nucleus of the amygdala and stria terminalis (Scalia \& Winans, 1976). Failure of behavioural oestrus was unlikely to be due to a lack of oestrogen, since PMSG and hCG in all but one pig resulted in a red and swollen vulva associated with a normal ovulatory response, but there may have been a deficiency in progesterone (Lisk, 1978). Inhibition of both the lordosis response and ovulation in bulbectomized pigs could be due primarily to inadequate production of gonadotrophin-releasing hormone. There is evidence that gonadotrophin-releasing hormones have a direct effect on lordosis behaviour in the rat (Sakuma \& Pfaff, 1980). It is possible that after bulbectomy in the pig a small reduction in gonadotrophin-releasing hormone might only affect the lordosis response, whereas a larger reduction in releasing factor might additionally prevent ovulation because of an inadequate release of gonadotrophins. A number of studies in the pig demonstrate the importance of olfactory stimuli originating in the boar to the lordosis response (see review by Booth, 1980; Perry, Patterson, MacFie \& Stinson, 1980) and the induction of puberty in gilts (Kirkwood et al., 1981; Kirkwood, Hughes \& Booth, 1983).

In conclusion, the data from this study and others indicate that olfactory stimuli and season are important modulators of the hypothalamic-pituitary-ovarian axis in the pig. The importance of these environmental factors may be diminished in the domestic pig compared with the wild pig, because of its controlled social and physical environment, but the degree to which photoperiodic stimuli might be acting with olfactory stimuli to regulate reproduction in the pig, as has been shown in the rat (Reiter, Petterborg, Trakulrungsi \& Trakulrungsi, 1980), is a topic requiring further investigation.

We thank Dr H. A. Garverick for help with the LH assays, Miss Carol White for histology and Mr A. Jones, Mr L. Smith and Mr J. Doggett for assistance with the pigs.

\section{References}

Booth, W.D. (1980) Endocrine and exocrine factors in the reproductive behaviour of the pig. Symp. zool. Soc. Lond. 45, 289-311.

Booth, W.D. \& Baldwin, B.A. (1980) Lack of effect on sexual behaviour or the development of testicular function after removal of olfactory bulbs in prepubertal boars. J. Reprod. Fert. 58, 173-182.

Booth, W.D., Baldwin, B.A., Poynder, T.M., Bannister, L.H. \& Gower, D.B. (1981) Degeneration and regeneration of the olfactory epithelium after olfac- 
tory bulb ablation in the pig: a morphological and electrophysiological study. $Q$. $J l$ Exp. Physiol. 66, 533-540.

Carter, C.S. (1973) Olfaction and sexual receptivity in the female golden hamster. Physiol. Behav. 10, 47-51.

Foxcroft, G.R. (1979) Endocrine changes in immature gilts-basis for early breeding. In Index of Research, pp. 16-17. Meat \& Livestock Commission, Bletchley.

Garverick, H.A., Polge, C. \& Flint, A.P.F. (1982) Oestradiol administration raises luteal LH receptor concentration in intact and hysterectomized pigs. $J$. Reprod. Fert. 66, 371-377.

Guthrie, H.D., Henricks, D.M. \& Handlin, D.L. (1972) Plasma estrogen, progesterone and luteinizing hormone prior to estrus and during early pregnancy in pigs. Endocrinology 91, 675-679.

Hafez, E.S.E. \& Signoret, J.P. (1969) The behaviour of swine. In The Behaviour of Domestic Animals, pp. 349390. Ed. E. S. E. Hafez. Williams \& Wilkins Company, Baltimore.

Henricks, D.M., Guthrie, H.D. \& Handlin, D.L. (1972) Plasma estrogen, progesterone and luteinizing hormone levels during the oestrous cycle in pigs. Biol. Reprod. 6, 210-218.

Hurtgen, J.P., Leman, A.D. \& Crabo, B. (1980) Seasonal influence on estrous activity in sows and gilts. $\mathrm{J} . \mathrm{Am}$. vet. med. Ass. 176, 119-123.

Kirkwood, R.N., Forbes, J.M. \& Hughes, P.E. (1981) The influence of boar contact on attainment of puberty in gilts after removal of the olfactory bulbs. J. Reprod. Fert. 61, 193-196.

Kirkwood, R.N., Hughes, P.E. \& Booth, W.D. (1983) Influence of boar-related odours on puberty attainment in gilts. Anim. Prod. (In press).

Lamond, D.R. (1958) Infertility associated with extirpation of the olfactory bulbs in female albino mice. Aust. J. exp. Biol. 36, 103-108.

Lisk, R.D. (1978) The regulation of sexual "heat". In Biological Determinants of Sexual Behaviour, pp. 425466. Ed. J. B. Hutchison. Wiley, Chichester.

Mauget, R. (1982) Seasonality of reproduction in the wild boar. In Control of Pig Reproduction, pp. 509-526. Eds D. J. A. Cole \& G. R. Foxcroft. Butterworths, London.

Meese, G.B. \& Baldwin, B.A. (1975) Effect of olfactory bulb ablation on maternal behaviour in sows. Appl. Anim. Ethol. 1, 379-386.

Murphy, M.R. (1976) Olfactory impairment, olfactory bulb removal, and mammalian reproduction. In Mammalian Olfaction, Reproductive Processes and Behavior, pp. 95-117. Ed. R. L. Doty. Academic Press, New York.

Newcomb, R., Booth, W.D. \& Rowson, L.E.A. (1977) The effect of oxytocin treatment on the levels of prostaglandin F in the blood of heifers. J. Reprod. Fert. 49, 17-24.

Niswender, G.D., Reichert, L.E., Jr \& Zimmerman, D.R. (1970) Radioimmunoassay of serum levels of luteinizing hormone throughout the estrous cycle in pigs. Endocrinology 87, 576-580.

Perry, G.C., Patterson, R.L.S., MacFie, H.J.H. \& Stinson, C.G. (1980) Pig courtship behaviour: pheromonal property of androstene steroids in male submaxillary secretion. Anim. Prod. 31, 191-199.

Reiter, R.J., Petterborg, L.J., Trakulrungsi, C. \& Trakulrungsi, W.K. (1980) Surgical removal of the olfactory bulbs increases sensitivity of the reproductive system of female rats to the inhibitory effects of late afternoon melatonin injections. J. exp. Zool. 212, 47-52.

Sakuma, Y. \& Pfaff, D.W. (1980) LH-RH in the mesencephalic central grey can potentiate lordosis reflex of female rats. Nature, Lond. 283, 566-567.

Scalia, F. \& Winans, S.S. (1976) New perspectives on the morphology of the olfactory system: olfactory and vomeronasal pathways in mammals. In Mammalian Olfaction, Reproductive Processes and Behavior, pp. 728. Ed. R. L. Doty, Academic Press, New York.

Signoret, J.P. \& Mauléon, P. (1962) Action de l'ablation des bulbs olfactifs sur les mechanismes de la reproduction chez la truie. Annls Biol. anim. Biochim. Biophys. 2, 167-174.

Vandenbergh, J.G. (1973) Effects of central and peripheral anosmia on reproduction of female mice. Physiol. Behav. 10, 257-261.

Ziecik, A., Goralska, M., Krzymowski, T. \& Pogorzelski, K. (1978) Isolation and purification of porcine $\mathrm{LH}$ for radioimmunoassay and radioreceptor assay. Bull. Acad. pol. Sci. Cl. II, Ser. Sci. Biol. 26, 739-744.

Received 28 May 1982 